\title{
ENZYME PROFILES AND ANTIMICROBIAL ACTIVITIES OF BACTERIA ISOLATED FROM THE KADIINI CAVE, ALANYA, TURKEY
}

\author{
Nihal Doğruöz-Güngör ${ }^{1, C}$, Begüm Çandıroğlu², and Gülşen Altuğ ${ }^{3}$
}

\begin{abstract}
Cave ecosystems are exposed to specific environmental conditions and offer unique opportunities for bacteriological studies. In this study, the Kadini Cave located in the southeastern district of Antalya, Turkey, was investigated to document the levels of heterotrophic bacteria, bacterial metabolic avtivity, and cultivable bacterial diversity to determine bacterial enzyme profiles and antimicrobial activities. Aerobic heterotrophic bacteria were quantified using spread plates. Bacterial metabolic activity was investigated using DAPI staining, and the metabolical responses of the isolates against substrates were tested using VITEK 2 Compact 30 automated micro identification system. The phylogenic diversity of fourty-five bacterial isolates was examined by $16 \mathrm{~S}$ rRNA gene sequencing analyses. Bacterial communities were dominated by members of Firmicutes (86 \%), Proteobacteria (12\%) and Actinobacteria (2\%). The most abundant genera were Bacillus, Staphylococcus and Pseudomonas. The majority of the cave isolates displayed positive proteolytic enzyme activities. Frequency of the antibacterial activity of the isolates was $15.5 \%$ against standard strains of Bacillus subtilis, Staphylococcus epidermidis, S.aureus, and methicillin-resistant S.aureus. The findings obtained from this study contributed data on bacteriological composition, frequency of antibacterial activity, and enzymatic abilities regarding possible biotechnological uses of the bacteria isolated from cave ecosytems.
\end{abstract}

\section{Introduction}

Caves are among the extreme environments in the world due to the low and generally stable temperature, minimum light, low nutrients, and high humidity (Palmer 1991; Tomczyk-Żak and Zielenkiewicz 2015). There are many cave types around the world and many different classifications have been used for these geological forms (Northup and Lavoie 2001; Engel 2011). Karstic caves are the most common, formed through geomorphological and microbiological processes (Engel 2010; Tisato et al., 2015; Bontognali et al., 2016). One of the critical subjects in cave research is the adaptation of cave microorganisms to extreme conditions. Previous studies have shown many different microorganis$\mathrm{ms}$ in caves and identified them from water bodies, on rocky surfaces, in guanos, and on sediments (Herzog Velikonja et al., 2014; Tomczyk-Żak and Zielenkiewicz 2015). Organic materials introduced by people, dripping water, floods, and animals, especially bats, create an environment that allows heterotrophic bacteria to grow in caves (Borda et al., 2014). Microorganisms may enter caves through different processes. Water, wind or air conditions may facilitate their transportation, or sometimes animals can carry microorganisms into caves (Romero 2009). Other transportation paths of microorganisms are created by humans, resulting in changes to native microbial communities. Difficult environmental conditions and low nutrients in cave environments create competition among microorganisms, which can produce antibiotics against each other in these environments (Bhullar et al., 2012). This natural process offers unique opportunities for biotechnological applications and possible uses of new bioactive substances, including new antibiotics.

Appliations of enzymes in techology is a rapidly-developing field, and is increasingly dependent on microbial enzymes. Microbial enzymes are more stable and are produced at a faster rate in greater amounts, making them the preferred source of enzymes. These enzymes take an important role in the diagnosis, treatment, industrial applications, biochemical tests and monitoring of various diseases. Moreover, diverse peptidases with particular biochemical properties have been identified from studies of microbial diversity of bacteria and fungi. This has provided a broad range of peptidase applications, particularly in the field of microbial biochemistry. For this reason, it is important to identify bacteriological community structure and metabolic characteristics in caves ecosytems.

The study has three main goals:

1. to investigate the levels of culturable aerobic heterotrophic bacteria (HPC), cultivable bacterial composition, and the frequency of metabolically-active bacteria in a cave ecosystem;

2. to detect the frequency of antimicrobial activities of the cave isolates against selected bacteria;

3. to evaluate biotechnological potential of the cave isolates regarding metabolic definition, biochemical reactions, and enzyme profiles.

${ }^{1}$ Istanbul University, Faculty of Science, Department of Biology, 34134 Vezneciler, Istanbul, Turkey

${ }^{2}$ Istanbul University, Institute of Sciences, 34134 Vezneciler, Istanbul, Turkey

${ }^{3}$ Istanbul University, Faculty of Aquatic Science, Department of Marine Biology, 34470 Laleli, Istanbul, Turkey

cCorresponding author: ndogruoz@istanbul.edu.tr 


\section{Materials and Methods}

\section{Cave background and sampling site}

Kadıini Cave, which is closed to tourist activities, is located in Obaköy, a village $3.8 \mathrm{~km}$ away from Alanya, a southeastern district of Antalya, Turkey (Fig. 1). Kadiini Cave is a horizontal cave with a length of $2027 \mathrm{~m}$ and a depth of $45 \mathrm{~m}$ (Turkey Cave Database). The first research in the Kadini Cave was conducted in 1957. During the research, human skeletons and archaeological finds such as cups, hearths, whorls and stone tools were found. The human skeletons are from 6000 years ago and showed that people used the cave as a living/shelter space. The entrance hall of the Kadini Cave is a gallery that is rich in terms of stalactites and stalagmites. It was a place of settlement during the Upper Paleolithic and the Early Bronze Age (Yılmazusta and Yakup Ipekoğlu 2019). Members of the Akdeniz University Cave Research Club (AKÜMAK) began investigating the Kadini Cave in 2008 and delving into the unexplored cave sections. In 2014, the Anatolian Speleology Association (ASPEG) started to support these studies. During sampling it was observed that the source of organic substances is guano and the water seeping through the walls. 650 bats of which 400 Rousettus aegyptiacus, 200 Rhinolophus blasii and 50 Miniopterus schreibersii were identified in the project entitled "Identification and Protection of Important Bat Caves in Turkey" that was carried out in 2012 in the Kadiini Cave (Coraman et al., 2012). There is also an underground stream at the end of the cave.

\section{Sample collection}

Water and soil samples were collected under aseptic conditions in the two different sites from the dark zone of the Kadini Cave (Fig. 1). The samples were maintained at $4{ }^{\circ} \mathrm{C}$ and transported within 24 hours to the laboratory.

\section{Variable environmental parameters of the sampling area}

The water samples collected from the cave were measured in situ in terms of temperature, $\mathrm{pH}$, dissolved oxygen, conductivity, total dissolved solids (TDS) and salinity using a portable multiparameter tool (a Hach Lange HQ40D multimeter). Air temperature and humidity at the two investigation sites were also measured by a portable temperature/ humidity meter. The Mann-Whitney $U$ test was used to determine statistically significant changes between measured environmental parameters of the two sample regions. All analyzes were performed using SPSS for Windows Version IBM 21 and $P<0.05$ was considered statistically significant.

\section{Bacteriological analyses}

For the analyses of bacteria, $200 \mathrm{~mL}$ water samples were concentrated with a $0.22 \mu \mathrm{m}$ pore size polyamide filter and then the filters were re-suspended in $20 \mathrm{~mL}$ sterile tap water using a homogenizator (IUL Instruments) for 2 min. For soil samples, one gram was weighed and homogenized in flasks containing $9 \mathrm{~mL}$ of sterile saline water. Serial dilutions of water and soil $\left(10^{-1}\right.$ to $\left.10^{-7}\right)$ were then prepared with sterile saline water and were used as an inoculum for the isolation and

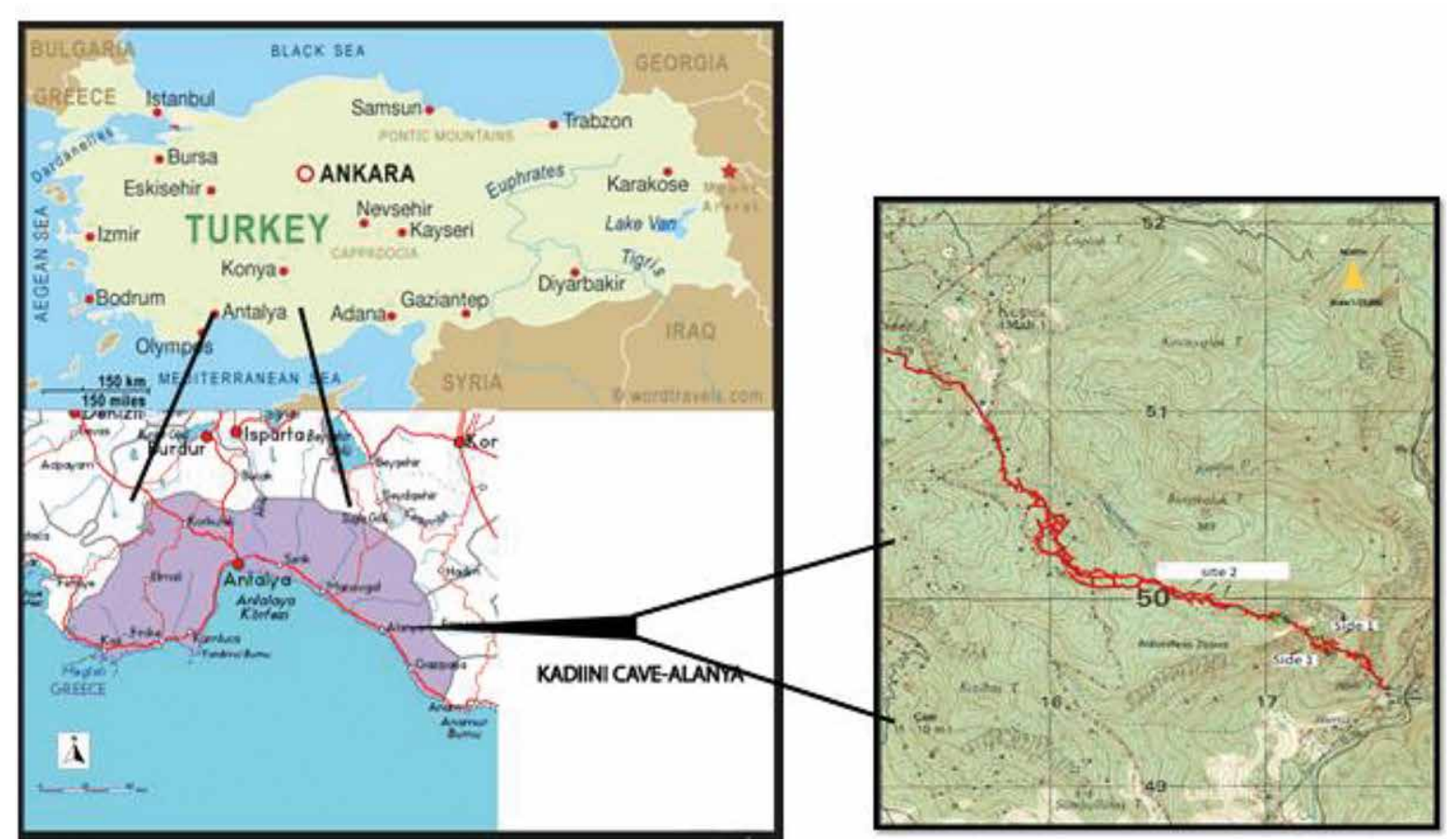

Figure 1. Map of the Kadini cave, Alanya, Antalya-Turkey. enumeration of HPC counts. To estimate the number of aerobic heterotrophic bacteria, triplicate $100 \mu \mathrm{L}$ volumes of each dilution $\quad\left(10^{-1}\right.$ to $10^{-7}$ ) were spread onto R2A (OXOID) agar plates. These plates were aerobically incubated at $28^{\circ} \mathrm{C}$ for 7 days. After the incubation, for each water and soil samples, the dilution that 
was counted contained between 30 and 300 colonies and expressed as the log of the total number of colony forming units (CFU) (Reasoner and Geldrich 1985).

Different colonies that grew on R2A plates were selected and stored at $-86{ }^{\circ} \mathrm{C}$ for subsequent testing of the isolates. To determine the direct viable counts of actively respiring bacteria and the total number of the bacteria cells, the redox dye, 5-cyano-2,3-ditolyl tetrazolium chloride (CTC) and the DNA-binding fluorochrome, 4',6-diamidino-2-phenylindole (DAPI) were used (Schwartz et al., 2003). CTC was used together with DAPI to distinguish between the metabolically active cells and the dead cells. The waters and soil suspensions $(900 \mu \mathrm{l})$ were incubated with the aliquots of a $50 \mathrm{mM}$ CTC redox dye solution to a final concentration of $5 \mathrm{mM}$ in the dark at $28^{\circ} \mathrm{C}$ for $4 \mathrm{~h}$. After the CTC incubation, $1.0 \mu \mathrm{g} / \mathrm{mL}$ DAPI solution was added to the samples and incubated for $1 \mathrm{~h}$ in the dark at $28^{\circ} \mathrm{C}$. After incubation, the samples were filtered by a vacuum filtration onto black $0.2 \mu \mathrm{m}$ pore size polycarbonate filters. The membrane was placed on a glass slide and examined under the oil immersion in a Nikon 80i microscope which was equipped with appropriate filters for CTC and DAPI. The number of bacteria was calculated from the counts of 20 randomly selected microscopic fields (at $1000 \times$ ). For all the bacterial counting, an eyepiece with a calibrated graticule was used. The estimation of the number of cells in each sample was calculated using (Dogruoz Güngör and Sanli Yurudu 2015)

$$
N=\frac{S n}{C V} D,
$$

where $N$ is the number of microorganisms per milliliter, $S$ is the real area of filtration, $n$ is the average number of microorganisms per field of vision, $C$ is the real area of microscopic range, $V$ is the volume of filtered sample, and $D$ is the sample dilution.

\section{$16 S$ rDNA amplification}

For the identification of isolates, their genomic DNA was isolated by using a bacterial DNA isolation kit (GeneAll Biotechnology, Seoul, Korea). The isolated DNA was amplified by 27F (5'-AGAGTTTGATCCTGGCTCAG-3') and 1492R (5'-GGTTACCTTGTTACGACTT-3') universal primers. The reaction was performed in a volume of $50 \mu \mathrm{L}$, comprising 20 nM each primer, $10 \mathrm{ng}$ of cDNA, $2.5 \mathrm{U}$ of Taq DNA polymerase (Bioline, UK), in a single block thermal cycler (Bio-rad, California, USA). The cycle conditions were at $95^{\circ} \mathrm{C}$ for $1 \mathrm{~min}$ initial DNA denaturation, followed by 35 cycles consisting of $15 \mathrm{~s}$ denaturation at $95^{\circ} \mathrm{C}, 15 \mathrm{~s}$ annealing at $55^{\circ} \mathrm{C}$, and $10 \mathrm{~s}$ extension at $72^{\circ} \mathrm{C}$. The PCR products were sequenced by the Sanger sorting method. Sequences were read by the ABI 3130 Sequencer (Applied Biosystems). Sequences and the top BLAST hit in NCBI were edited. The16S rDNA sequences were deposited in GenBank (NCBI) under the accession numbers MK491005-MK491049.

\section{Biochemical characterization and enzyme profiles of the isolates}

To determine biochemical characterization and enzyme profiles of bacterial isolates, a Gram stain, a catalase test, and an oxidase test were conducted. Then they were identified by using GN (Gram-negative fermenting and non-fermenting bacilli), GP (Gram-positive cocci and non-spore-forming bacilli) and BCL (Gram-positive spore-forming bacilli) cards in the automated micro identification system, specialized for environmental samples with industrial software, VITEK 2 Compact 30 (bioMerieux, France). The identification cards are predicated upon the established biochemical methods and recently developed substrates. The calculations are conducted on raw data and compared to thresholds to designate reactions for each test (Pincus 2005).

\section{Evaluation of antimicrobial activity}

By using inhibition zone technique, antimicrobial activity of the isolated bacteria were tested against bacterial strains, including pahogens [S.epidermidis (ATCC 12228), B.subtilis (ATCC 6633), S.aureus (ATCC 6538), P.aeruginosa (ATCC 9027), E.coli (ATCC 8739), methicillin resistant Staphylococcus aureus (MRSA) (ATCC 33591) and vancomycin-resistant enterococci (VRE) (ATCC 51299)]. Each cave isolate was suspended in saline solution to obtain a concentration of $3 \times 10^{8} \mathrm{CFU} / \mathrm{mL}$, then $0.1 \mathrm{~mL}$ of the suspensions were spread onto Muller Hinton Agar plates with a Drigalski spatula. Suspensions of the standard bacteria were prepared in saline solution with a final concentration of $1.5 \times 10^{8} \mathrm{CFU} / \mathrm{mL}$ then spread $(0.1 \mathrm{~mL})$ on the surface of Muller Hinton Agar plates using a Drigalski spatula. A small part $(6 \times 6 \mathrm{~mm})$ of each cave isolate growth was cut and placed on the surface of the inoculated standard strains plates with a nichrome wire loop.

A small part of sterile Muller Hinton agar $(6 \times 6 \mathrm{~mm})$ was placed on to surface of the inoculated standard strains plate as negative control. Disc of standard antibacterial agents erythromycin (15 $\mu \mathrm{g})$ (OXOID discs, UK), vancomycin (30 $\mu \mathrm{g})$ (OXOID discs, UK) , neomycin $(10 \mu \mathrm{g})$ (OXOID discs, UK), gentamicin (10 $\mu \mathrm{g})$ (OXOID discs, UK) and tetracycline $(10 \mu \mathrm{g})\left(\mathrm{OXOID}\right.$ discs, UK) were used as positive control. All the plates were incubated at $37^{\circ} \mathrm{C}$, for $18-24$ hours. After incubation, the antimicrobial activity was evaluated by measuring the inhibition zone diameter. Each test was performed twice and the average of the results was taken (Cotuk et al., 2005). 


\section{Results}

\section{Physicochemical Analysis}

The water and soil samples taken from the two designated sites of the dark zone of the Kadini Cave were analyzed. The air temperature measurements of the samples collected from Site 1 and Site 2 of the cave were $18.9^{\circ} \mathrm{C}$ and $17.5^{\circ} \mathrm{C}$ and the air humidity values were $92 \%$ and $86 \%$. The environmental parameters of the water samples in the Kadiini Cave are shown in Table 1. Conductivity, TDS and salinity values of the Site 1 were statistically higher than the Site 2 $(p<0.05)$.

Table 1. The Physico-Chemical parameters of the water samples from Kadıini Cave in December 2014.

\begin{tabular}{ccc}
\hline Parameters & Site 1 & Site 2 \\
\hline Water temperature $\left({ }^{\circ} \mathrm{C}\right)$ & 17.8 & 17.4 \\
$\mathrm{pH}$ & 7.87 & 8.82 \\
Conductivity $(\mu \mathrm{S} / \mathrm{cm})$ & 442 & 294 \\
$\operatorname{TDS}(\mathrm{mg} / \mathrm{L})$ & 211.5 & 140.3 \\
\hline
\end{tabular}

\section{Enumeration, isolation, and identification of cultur-} able bacteria from Kadini Cave

The levels of heterotrophic aerobic bacteria from Site 1 and Site 2 from the dark zone of the Kadini Cave are given in Table 2. The total (live + dead) and the live bacteria count (log cell/mL, log cell/g) of the water and soil samples are shown in Table 2. By using DAPI-CTC staining, we showed that the total viable bacterial count is higher than the cultured bacterial count.

Table 2. Total (live + dead), live bacteria count (log cell/mL, log cell/g), viability (\%) and total culturable aerobic heterotrophic bacteria of water and soil samples from Kadıini Cave in December 2014.

\begin{tabular}{ccccc}
\hline Bacteria Measures & Site 1 Water & Site 1 Soil & Site 2 Water & Site 2 Soil \\
\hline Total bacteria count $^{\mathrm{a}}$ & 10 & 10.6 & 7.8 & 11 \\
Live bacteria count $^{\mathrm{b}}$ & 9.8 & 10 & 7.6 & 37.5 \\
$\quad$ Viability (\%) $_{\text {Culturable aerobic heterotrophic }}^{\text {bacteria (log CFU) }}$ & 41.7 & 21 & 26.3 & $3.2 \pm 0.6$ \\
\hline
\end{tabular}

\footnotetext{
a Total bacteria' counts determined by DAPI + CTC staining
}

' Live bacteria' counts determined by CTC staining.

Fourty-five bacteria were isolated from the water and soil samples collected from Kadiini Cave. After amplification of the 16S rRNA gene for each isolate, three phylogenetic groups: Firmicutes (86\%), Proteobacteria (12\%) and Actinobacteria (2\%) were recorded. The composition of cultivable heterotrophic aerobic bacteria, the names and distribution percentage of the identified genera are shown in Table 3. After phylogenetic analysis, a strong domination of Gram-positive aerobic heterotrophic bacteria was established (89\%), belonging to four genera: Bacillus, Viridibacillus, Staphylococcus, and Brevibacterium. Gram-negative isolates (11\%) were represented by two genera: Pseudomonas and Paracoccus (Table 4).

\section{Biochemical characterization and enzyme profiles of the isolates}

Biochemical characterization and enzyme profiles of the bacilli (BCL and spore-forming) (Fig. 2), Gram positive (Fig. 3), and Gram negative (Fig. 4) isolates are determined as a result of the analyses conducted by using the automated micro identification system VITEK 2 Compact 30 (bioMerieux, France). Seventy-eight percent of all isolates have a positive reaction for production of the TyrA enzyme. The percentage of presence of PRY enzyme is found to be high in $\mathrm{BCL} /$ spores and GN strains. In addition, the percentage of ProA enzymes is higher in GN and GP strains. The positive reaction percentages of all isolates (BCL, GP, and $\mathrm{GN}$ ) against the tested substrates are displayed in Figures 2-4.

\section{Antimicrobial activity of the isolates}

The cave bacterial isolates were screened to understand their antimicrobial activities against $S$. epidermidis (ATCC 12228), B.subtilis (ATCC 6633), S.aureus (ATCC 6538), P.aeruginosa (ATCC 9027), E.coli (ATCC 8739), MRSA (ATCC 33591), and VRE (ATCC 51299) strains by the agar plug diffusion method. The commercial antibacterial agents were used against all tested standard strains (Table 5). In this study, seven bacteria, isolated from the water and soil samples, displayed antimicrobial activity (15.5\%) against the control bacteria.

\section{Discussion}

This cave is unexplored from the microbiological point of view, making it interesting to study the bacterial diversity for possible industrial applications. In this study, the total viable bacteria counts were recorded to be higher than the culturable bacteria counts in the samples collected from Kadini Cave. It was documented that many species of bacteria en- 
Table 3. The composition of cultivable heterotrophic aerobic bacteria and percentage distribution of the identified genus.

\begin{tabular}{cccc}
\hline Phylum & Class & Genus & $\%$ \\
\hline Firmicutes & Bacilli & Bacillus & 67 \\
& & Viridibacillus & 2 \\
& & Staphylococcus & 18 \\
Actinobacteria & Actinobacteria & Brevibacterium & 2 \\
Proteobacteria & Alphaproteobacteria & Paracoccus & 2 \\
& Gammaproteobacteria & Pseudomonas & 9 \\
\hline
\end{tabular}

Table 4. Closest match of the bacterial isolates based on 16S rRNA gene phylogeny analysis.

\begin{tabular}{|c|c|c|c|}
\hline $\begin{array}{l}\text { Isolation ID } \\
\text { (accession \#) }\end{array}$ & $\begin{array}{l}\text { Nearest relativea/ } \\
\text { Bacterial division }\end{array}$ & $\begin{array}{c}\text { Accession \# } \\
\text { (nearest relativea) }\end{array}$ & $\%$ Similarity \\
\hline 1 (MK491005) & Bacillus cereus & MH041184 & 99 \\
\hline 4 (MK491021) & Bacillus cereus & KY316431 & 99 \\
\hline 5 (MK491027) & Bacillus cereus & KX941839 & 99 \\
\hline 16 (MK491045) & Bacillus cereus & MG563677 & 99 \\
\hline 28 (MK491024) & Bacillus cereus & MG563677 & 98 \\
\hline 38 (MK491036) & Bacillus cereus & MG563677 & 98 \\
\hline 6 (MK491032) & Bacillus cereus & MG563677 & 99 \\
\hline 20 (MK491023) & Bacillus pumilus & KC182057 & 98 \\
\hline 30 (MK491035) & Bacillus pumilus & KF641848 & 98 \\
\hline 31 (MK491041) & Bacillus pumilus & HG799995 & 98 \\
\hline 39 (MK491042) & Bacillus pumilus & KF641848 & 99 \\
\hline 42 (MK491014) & Bacillus pumilus & KF641848 & 99 \\
\hline 46 (MK491037) & Bacillus pumilus & KF641848 & 98 \\
\hline 47 (MK491043) & Bacillus pumilus & KC182057 & 99 \\
\hline 50 (MK491015) & Bacillus pumilus & KY127313 & 98 \\
\hline 37 (MK491030) & Bacillus pumilus & KY127313 & 98 \\
\hline 11 (MK491016) & Bacillus niacini & KT720235 & 97 \\
\hline 14 (MK491033) & Bacillus litoralis & KU983814 & 98 \\
\hline 2 (MK491010) & Bacillus thuringiensis & LC146715 & 99 \\
\hline 22 (MK491034) & Bacillus toyonensis & KY649418 & 98 \\
\hline 33 (MK491008) & Bacillus amyloliquefaciens & СР018902 & 98 \\
\hline 24 (MK491046) & Bacillus weihenstephanensis & KF831381 & 99 \\
\hline 48 (MK491049) & Bacillus mycoides & MH169305 & 99 \\
\hline 32 (MK491047) & Bacillus subtilis & EU883786 & 99 \\
\hline 13 (MK491028) & Viridibacillus arvi & KU894793 & 99 \\
\hline 12 (MK491022) & Bacillus sp. & MG548383 & 99 \\
\hline 7 (MK491038) & Bacillus sp. & MH628022 & 99 \\
\hline 10 (MK491011) & Bacillus sp. & FJ348046 & 97 \\
\hline 21 (MK491029) & Bacillus sp. & KM108632 & 97 \\
\hline 34 (MK491013) & Bacillus sp. & КT316413 & 99 \\
\hline 25 (MK491007) & Bacillus sp. & MH698798 & 98 \\
\hline
\end{tabular}


Table 4. (Continued).

\begin{tabular}{cccc}
\hline $\begin{array}{c}\text { Isolation ID } \\
\text { (accession \#) }\end{array}$ & $\begin{array}{c}\text { Nearest relativea/ } \\
\text { Bacterial division }\end{array}$ & $\begin{array}{c}\text { Accession \# } \\
\text { (nearest relativea) }\end{array}$ & \% Similarity \\
\hline $\mathbf{3 5}$ (MK491019) & Staphylococcus warneri & HG799993 & KX453876 \\
$\mathbf{3 6}$ (MK491025) & Staphylococcus warneri & KX349994 & 96 \\
$\mathbf{1 7}$ (MK491006) & Staphylococcus warneri & KU922389 & 99 \\
$\mathbf{1 5}$ (MK491039) & Staphylococcus pasteuri & KU922319 & 98 \\
$\mathbf{1 9}$ (MK491017) & Staphylococcus pasteuri & KX926554 & 98 \\
$\mathbf{4 3}$ (MK491020) & Staphylococcus epidermidis & KX349995 & 99 \\
$\mathbf{4 0}$ (MK491048) & Staphylococcus epidermidis & EU177793 & 99 \\
$\mathbf{8}$ (MK491044) & Staphylococcus sp & MF716680 & 97 \\
$\mathbf{2 7}$ (MK491018) & Pseudomonas plecoglossicida & CP015992 & 97 \\
$\mathbf{4 4}$ (MK491026) & Pseudomonas sp. & KX301316 & 98 \\
$\mathbf{4 5}$ (MK491031) & Pseudomonas sp. & KX301316 & 99 \\
$\mathbf{4 9}$ (MK491009) & Pseudomonas sp & CP030239 & 98 \\
$\mathbf{2 3}$ (MK491040) & Paracoccus mutanolyticus & KU922165 & 99 \\
\hline
\end{tabular}

Based upon a Blast search of the NCBI database.

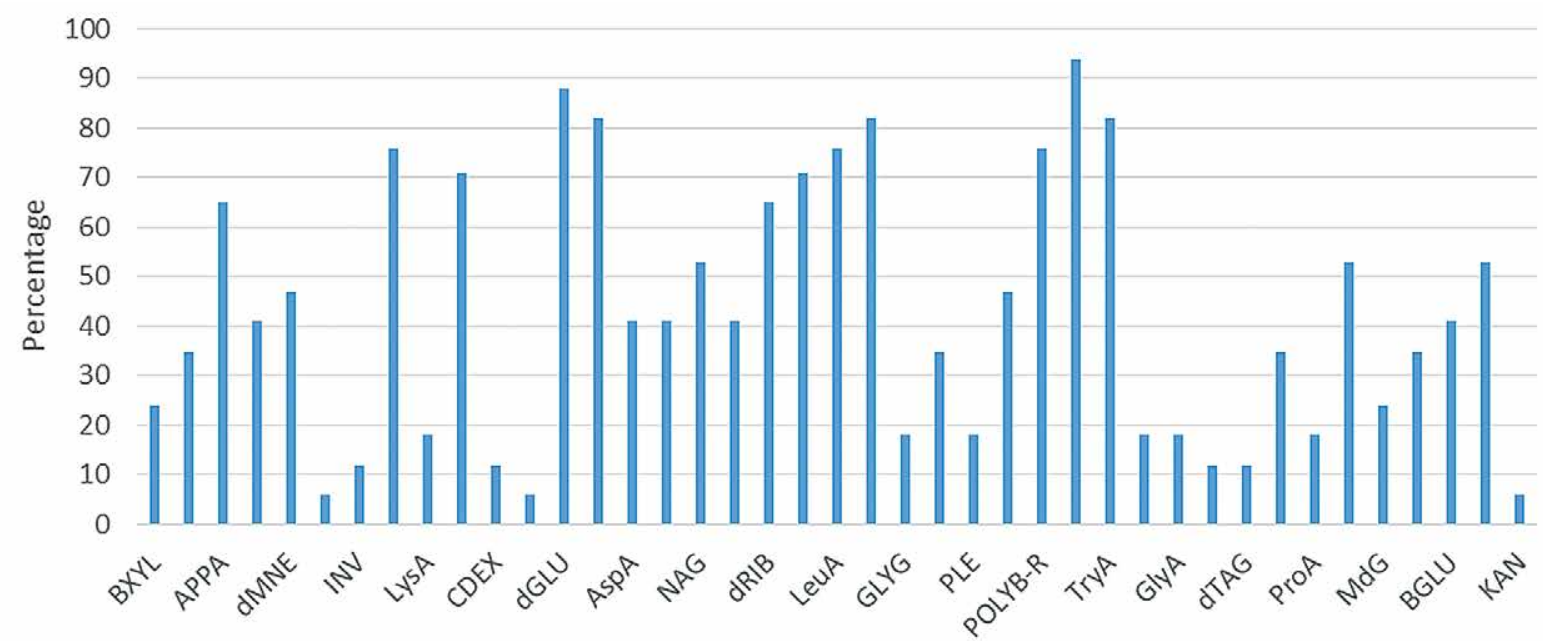

Enzymatic reactions

Figure 2. Biochemical characterization and enzyme profiles of the Gram-positive spore-forming bacilli (BCL) isolated from Kadini Cave. VBNC phase under these conditions. The VBNC phase is also described as the genetically programmed physiological response of bacterial cells that are fighting to survive under environmental stress (Besnard et al., 2002).

Conductivity is the capacity of water to conduct an electric current. At the same time it is an indirect measurement of salinity and total dissolved solids (TDS) content (AI Dahaan et al., 2016). In our study, it was determined that the conductivity, TDS and salinity values of Site 1 were statistically higher than Site $2(p<0.05)$. Conductivity, TDS and salinity are strongly related to the aquifer rock geochemistry (Bakalowicz 1994). These results may indicate that Site 2 is fed by a water source.

In our study, the microbial communities were dominated by the members of Firmicutes (85\%), followed by Proteobacteria (13\%) and Actinobacteria (2\%). These phyla are encountered in various microbiological studies conducted through culture-based or molecular techniques (Barton 2015). Firmicutes are frequently encountered under extreme conditions; 


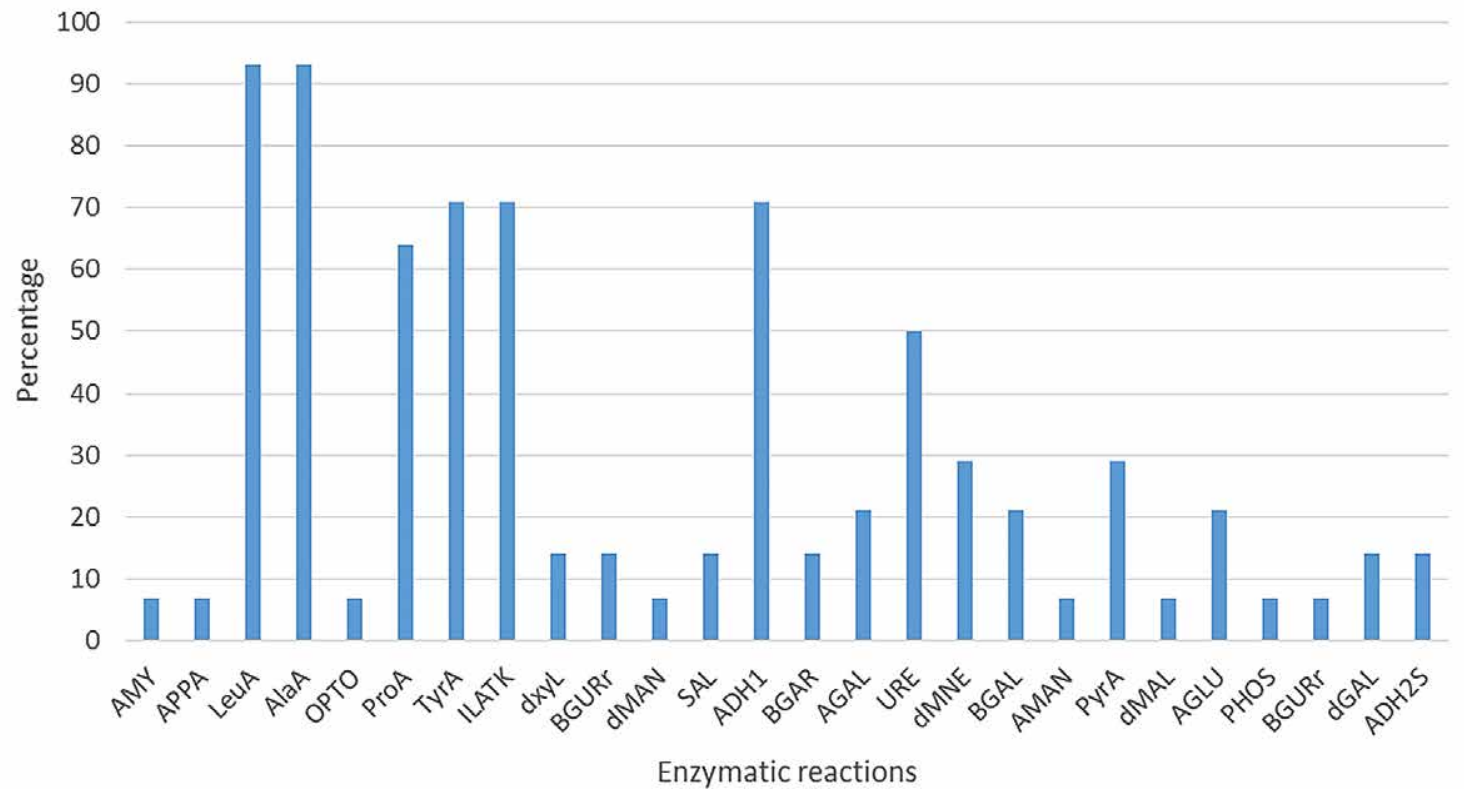

Figure 3. Biochemical characterization and enzyme profiles of the Gram-positive cocci and non-spore-forming bacilli (GP) isolated from Kadini Cave.

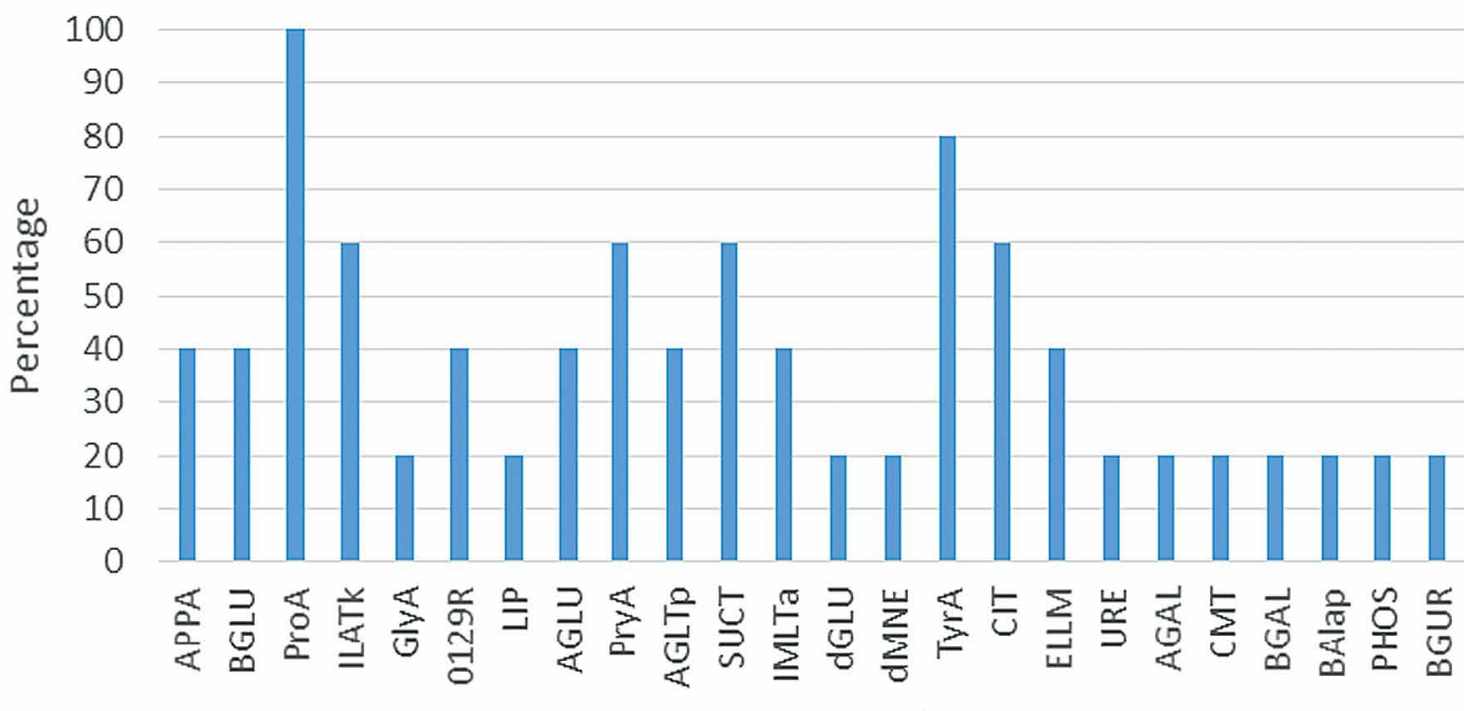

Enzymatic reactions

Figure 4. Biochemical characterization and enzyme profiles of the Gram-negative fermenting and non-fermenting bacilli (GN) isolated from Kadini Cave.

2009). In the present study, while Bacillus were the most common genera represented by nine species, Staphylococcus follow it as the second most common genera with three species. The most common species belonging to Bacillaceae family was Bacillus pumilus, followed by Bacillus cereus. Biochemical and biomolecular analyses showed that most calcifying strains are members of the genus Bacillus sp. and Pseudomonas sp. (Shirakawa et al., 2011, Banerjee and Joshi 2016). S.epidermidis, S. pasteuri and S.warneri isolated from Kadiini Cave belong to typical human and animal microbiota like S.aureus, these species are considered pathogens (Lavoie and Northup 2005; Mulec et al., 2017). These studies show that these bacteria are ubiquitous and have been previously identified in karstic caves (Herzog Velikonja et al., 2014; Ma et al., 2015; Banerjee and Joshi 2016; Iţcuş et al., 2016).

The types of microbial extracellular enzyme activities imply the kinds of nutrients present in that environment. Khizhnyak et al. (2003) reported that cultures from Siberian caves produced a low-level of amylolytic enzymes compared to other enzyms, which explains the abscence of natural sources of starch in these environment. In our study, it has been determined that $78 \%$ of all isolates could break the aril-amid bonds in tyrosine. Additionally, all Gram positive 
Table 5. The inhibition zones $(\mathrm{mm})$ of standard bacterial strains against experimental isolates and some antibiotics. (-) no inhibition.

\begin{tabular}{|c|c|c|c|c|c|c|c|}
\hline \multirow[b]{2}{*}{ Isolates (ID) } & \multicolumn{7}{|c|}{ Bacterial inhibition zones $(\mathrm{mm})$} \\
\hline & S.epidermidis & B.subtilis & S.aureus & P.aeruginosa & E.coli & MRSA & VRE \\
\hline Brevibacterium frigoritolerans ( 23 ) & 8 & 12 & - & - & - & - & - \\
\hline Bacillus thuringiensis ( 2) & 10 & 12 & - & - & - & - & - \\
\hline Bacillus weihenstephanensis ( 24 ) & 12 & 14 & - & - & - & - & - \\
\hline Bacillus cereus (28) & - & 8 & - & - & - & - & - \\
\hline Bacillus cereus (1) & 14 & 14 & - & - & - & - & - \\
\hline Bacillus sp. (12) & - & 10 & - & - & - & - & - \\
\hline Pseudomonas sp. (44) & - & - & 16 & - & - & 10 & - \\
\hline Erythromycin & $34(S)$ & $34(S)$ & $18(\mathrm{I})$ & - & 12 & - & - \\
\hline Vancomycin & $40(S)$ & $26(S)$ & $16(R)$ & - & - & $9(\mathrm{R})$ & $28(S)$ \\
\hline Neomycin & $18(I)$ & $24(S)$ & - & $10(R)$ & $10(\mathrm{R})$ & $14(R)$ & - \\
\hline Gentamicin & $24(S)$ & $32(S)$ & $16(S)$ & $22(S)$ & $22(S)$ & $20(S)$ & - \\
\hline Tetracyclin & $28(S)$ & $32(S)$ & $12(\mathrm{R})$ & $10(R)$ & $20(S)$ & - & $14(R)$ \\
\hline
\end{tabular}

isolates displayed positive arylamidases reaction that were specific for leucine and alanine at varying rates between $76 \%$ and $93 \%$. According to our results of the L-proline-arylamidase test, all of Gram-negative bacteria and $64 \%$ of Gram-positive bacteria were positive.

A range of enzymatic activities was found in bacteria from the Kadini Cave. Most of these enzymes have proteolytic activity, of which $96 \%$ of BCL isolates, $96 \%$ of GP isolates, and $100 \%$ of GN isolates produce at least one enzyme required for protein metabolism. Tomova et al. (2013) reported that $87 \%$ of Magura Cave isolates have proteolytic activity. Tyrosine residues formed by the breakdown of tyrosine by arylamidase and proline residues formed by the breakdown of L-Proline by arylamidase have very important metabolic functions for the cell in bacteria. They are effective in cell metabolic activities and formation of secondary metabolites (Patterson et al., 1963; Westley et al., 1967; Levit 1981; Kohl et al., 1988; Shibasaki et al., 1999; Nagata et al., 2003; Curtis et al., 2004; Whitmore and Lamont 2012). Because of their possession of different proteolytic enzymes, they can survive in environments such as caves that are poor in nutrients. Glycosidases are the most commonly found enzyme group after proteolytic enzymes in cave isolates. Our study has shown a positive proteolytic enzymes activity of the bacilli isolates, as well as the ones regarding carbonhytrate catabolism.

Antimicrobial components have a central part in mankind's struggle against infections. Nevertheless, because of their various resistance mechanisms, native or acquired, many antibiotics are losing their function every year (Kmietowicz, 2017). Nowdays, the existance of microorganisms with different enzymatic and antimicrobial effects has been proven in extreme ecosystems and researchers have started to focus on caves as one extreme environment (Lavoie, 2015; Man et al., 2015). Certain microorganisms isolated from cave ecosytems have been proven to display antimicrobial activity (Cheeptham et al., 2013; Tomova et al., 2013; Klusaite et al., 2016). Our results showed that $15.5 \%$ of the isolates have antimicrobial activity against B.subtilis and S.epidermidis and the others ineffective. In addition, isolate number 7 is effective against S.aureus and methicillin-resistant S.aureus. Yücel and Yamaç (2010) investigated 19 karstic caves in Turkey. They reported that the antibiotic extract that they obtained from these caves had bactericidal effect on the model resistant strains in lower concentrations than the antibiotic streptomycin. An important part of these secondary metabolites are potent antibiotics, which has made Bacillus one of the major antibiotic-producing organisms exploited by the pharmaceutical industry (Ghosh et al., 2017).

\section{Conclusions}

The bacteria isolated from Kadini Cave displayed a potential related for use not only products but also vegetative forms in biotechnological applications such as biodegredation, enzyme production, antimicrobial or antitumoral drugs, and bacterial self-healing concrete (Jariyal et al., 2015; Kanmani et al., 2015; Zhang et al., 2015; Lee and Park, 2018). In addition, research conducted in 2018 have used many bacterial species isolated from the Kadini Cave against phytopathogens and entomopathogen (Durairaj et al., 2018, Karungu et al., 2018).

In our study of the bacterial communities of Kadiini Cave, the antimicrobial activity and the biotechnological use potentials were investigated. The study results showed that the most commonly detected bacterial genus in cave 
ecosytem was Bacillus (Firmicutes). Although there were differences in the bacterial species detected in Kadiini Cave, our results indicated that Firmicutes, Proteobacteria and Actinobacteria are the most common group with biochemical peculiarities of the isolated bacteria against tested substrates. There is the biotechnological potentiality of these strains for further studies and industrial applications. The results obtained in our study contributed to understanding the heterotrophic aerobic culturable bacteria profile of karstic Kadıini Cave ecosytems regarding a source of industrially important enzymes and antimicrobial compounds.

\section{Acknowledgements}

The authors thank Istanbul University Scientific Project Unit (BAP Project FBA-2017-25580 and BEK-2017-27261) for their financial support. The author would like to thank the Anatolian Speleology Association, the Akdeniz University Cave Research Club and Ender USULOĞLU for sampling, mapping, and their contributions during this research.

\section{References}

Al Dahaan, S., Al-Ansari, N., Knutsson, S., 2016, Influence of groundwater hypothetical salts on electrical conductivity total dissolved solids: Engineering, v. 8, no.11, p. 823-830. https://doi.org/10.4236/eng.2016.811074.

Bakalowicz, M., 1994, Water Geochemistry: Water Quality and Dynamics, in Gibert, J., Danielopol, D.L., and Stanford, J.A., eds., Groundwater Ecology: Academic Pres, p. 97-127.

Banerjee, S., and Joshi, S., 2016, Culturable bacteria associated with the caves of Meghalaya in India contribute to speleogenesis: Journal of Cave and Karst Studies, v. 78, p. 144-157. https://doi.org/10.4311/2015mb0131.

Barton, H.A., 2015, Starving artists: Bacterial oligotrophic heterotrophy in caves: in Engel. A.S., and DeGruyter, W, eds., Life in Extreme Environments: Microbial Life of Cave Systems, Berlin, Germany, p. 79-95.

Besnard, V., Federighi, M., Declerq, E., Jugiau, F., and Cappelier, J.M., 2002, Environmental and physico-chemical factors induce VBNC state in Listeria monocytogenes: Veterinary Research, v. 33, p. 359-370. https://doi.org/10.1051/vetres:2002022.

Bontognali, T.R.R., D’Angeli, I.M., Tisato, N., Vasconcelos, C., Bernasconi, S.M., Gonzales E.R.G., and De Waele, J., 2016, Mushroom speleothems: stromatolites that formed in the absence of phototrops: Frontiers of Earth Science, v. 4, no. 49, p.1-8. https://doi.org/10.3389/feart.2016.00049.

Borda, D.R., Năstase-Bucur, R.M., Spînu, M., Uricariu, R., and Mulec, J., 2014, Aerosolized microbes from organic rich materials: Case study of bat guano from caves in Romania: Journal of Cave and Karst Studies, v. 76, p. 114-126. https://doi.org/10.4311/2013MB0116. https://doi. org/10.4311/2013MB0116.

Bhullar, K., Waglechner, N., Pawlowski, A., Koteva, K., Banks, E.D., Johnston, M.D., Barton H.A., Wright, G.D., 2012, Antibiotic resistance is prevalent in an isolated cave microbiome: PloS One, v. 7, no. 4, p. 1-11. https://doi:10.1371/journal .pone.0034953.

Cheeptham, N., Sadoway, T., Rule, D., Watson, K., Moote, P., Soliman, L.C., Azad, N., Donkor, K. K., and Horne, D., 2013, Cure from the cave: volcanic cave actinomycetes and their potential in drug discovery: International Journal of Speleology, v .42, p. 35-47. http://dx.doi. org/10.5038/1827-806X.42.1.5.

Coraman and Celik, 2012, Identification and Protection of Important Bat Caves in Turkey: Project final report, Project ID: 0534710.

Cotuk, A., Doğruöz, N., Zeybek, Z., Kimiran-Erdem A., and İlhan Sungur, E., 2005, The effects of Pseudomonas and Aeromonas strains on Legionella pneumophila growth: Annals of Microbiology, v. 55, p. 219-224.

Curtis, J., Shearer, G., and Kohl, D.H., 2004, Bacteroid proline catabolism affects N2 fixation rate of drought-stressed soybeans: Plant physiology, v. 136, no. 2, p. 3313-3318. https://doi/10.1104/pp.104.044024.

Doğruöz Güngör, N., and Sanli Yurudu, N.O., 2015, Evaluation of bacterial resistance to chloramine T biocide and effects on rifampicin antibiotic susceptibility as a consequence of biocide usage in Cooling System Biofilm including Legionella pneumophila: The Battle Against Microbial Pathogens, Basic Science, Technological Advances and Educational Programs, p.923-929

Durairaj, K., Velmurugan, P., Park, J.H., Chang, W.S., Park, Y.J., Senthilkumar, P., Choi, K.M., Lee, J.H., and Oh, B.T., 2018, An investigation of biocontrol activity Pseudomonas and Bacillus strains against Panax ginseng root rot fungal phytopathogens: Biological Control, v. 125, p. 138-146. https://doi.org/10.1016/j.biocontrol.2018.05.021.

Engel, A.S., 2010, Microbial diversity of cave ecosystem, in Barton, L.L, Mandi, M., Loy, and A. eds, Geomicrobiology, Molecular and Environmental Perspective: Springer Science and Business Media BV, p. 219-238. https://doi.org/10.1007/978-90-481-9204-5.

Engel, A.S., 2011, Karst Ecosystems, in Reitner, J., and Thiel, V. eds, Encyclopedia of Geobiology, Encyclopedia of Earth Sciences Series: Springer, Dordrecht, p. 521-531. https://doi.org/10.1007/978-1-4020-9212-1_125.

Ghosh, S., Kuisiene, N., and Cheeptham, N., 2017, The cave microbiome as a source for drug discovery: Reality or pipe dream?: Biochemical Pharmacology, v. 134, p. 18-34. https://doi.org/10.1016/j.bcp.2016.11.018.

Herzog Velikonja, B., Tkavc, R., and Pašić, L., 2014, Diversity of cultivable bacteria involved in the formation of macroscopic microbial colonies (cave silver) on the walls of a cave in Slovenia: International Journal of Speleology, v. 43, p. 45-56. https://doi.org/10.5038/1827-806x.43.1.5.

Iţcuş, C., Pascu, M.D., Brad, T., Perşoiu, A., and Purcarea, C., 2016, Diversity of cultured bacteria from the perennial ice block of Scarisoara Ice Cave, Romania: International Journal of Speleology, v. 45, p. 89-100. https://doi.org/10.5038/1827-806x.45.1.1948.

Jariyal, M., Gupta, V.K., Mandal, K., and Jindal, V., 2015, Brevibacterium frigoritolerans as a novel organism for the bioremediation of phorate: Bulletin of Environmental Contamination and Toxicology, v. 95, p. 680-686. https://doi.org/10.1007/s00128-015-1617-2.

Kanmani, P., Kumaresan, K., and Aravind, J., 2015, Utilization of coconut oil mill waste as a substrate for optimized lipase production, oil biodegradation and enzyme purification studies in Staphylococcus pasteuri: Electronic Journal of Biotechnology, v. 18, p. 20-28. https://doi. org/10.1016/j.ejbt.2014.11.003.

Karungu, S., Huang, D., Atoni, E., Waruhiu, C., Agwanda, B., Hu, X., and Yuan, Z., 2018, Isolation, identification, and evaluation of mosquito entomopathogenic Bacillus species and related genera from randomly selected sites in Kenya: African Journal of Microbiology Research, v. 12, p. 290-299. https://doi.org/10.5897/ajmr2018.8824.

Khizhnyak S.V., Tausheva I.V., Berezikova A.A., Nesterenko E.V, and Rogozin D.Y., 2003, Psychrophilic and psychrotolerant heterotrophic microorganisms of middle Siberian karst cavities: Russian Journal of Ecology, v. 34, p. 231-235.

Klusaite, A., Vickackaite, V., Vaitkeviciene, B., Karnickaite, R., Bukelskis, D., Kieraite-Aleksandrova, I., and Kuisiene, N., 2016, Characterization of antimicrobial activity of culturable bacteria isolated from Krubera-Voronja Cave: International Journal of Speleology, v. 45, p. 8. https://doi. org/10.5038/1827-806x.45.3.1978. 
Kmietowicz, Z., 2017, Few novel antibiotics in the pipeline, WHO warns, BMJ: British Medical Journal (Online), BMJ 2017: 358: j4337. https://doi. org/10.1136/bmj.j4339.

Kohl, D.H., Schubert, K.R., Carter, M.B., Hagedorn, C.H., and Shearer, G., 1988, Proline metabolism in N2-fixing root nodules: energy transfer and regulation of purine synthesis: Proceedings of the National Academy of Sciences, v. 85, no. 7, p. 2036-2040. https://doi.org/10.1073/ pnas.85.7.2036.

Lavoie, K.H., 2015, A grand, gloomy, and peculiar place: Microbiology in the Mammoth Cave Region: Life in Extreme Environments: Microbial Life of Cave Systems: Engel, AS, Ed, De Gruyter, Berlin, Germany, p. 47-78. https://doi.org/10.1515/9783110339888-005.

Lavoie, K.H., and Northup, D.E., 2005, Bacteria as indicators of human impact in caves: National Cave and Karst Management Symposium, p. 40-47.

Lee, Y. S., and Park, W., 2018, Current challenges and future directions for bacterial self-healing concrete: Applied Microbiology and Biotechnology, v. 102, p. 3059-3070. https://doi.org/10.1007/s00253-018-8830-y.

Levitt, M., 1981, Effect of proline residues on protein folding: Journal of molecular biology, v. 145, no. 1, p. 251-263. https://doi.org/10.1016/00222836(81)90342-9.

Ma, Y., Zhang, H., Du, Y., Tian, T., Xiang, T., Liu X., Wu, F., An, L., Wang, W., 2015, The community distribution of bacteria and fungi on ancient wall paintings of the Mogao Grottoes: Scientific Reports, v. 5, p. 7752. https://doi.org/10.1038/srep07752.

Man, B., Wang, H., Xiang, X., Wang, R., Yun, Y., and Gong, L., 2015, Phylogenetic diversity of culturable fungi in the Heshang Cave, central China: Frontiers in Microbiology, v. 6, no. 1158, p. 1-11. https://doi.org/10.3389/fmicb.2015.01158.

Mulec, J., Oarga-Mulec, A., Šturm, S., Tomazin, R., Matos, T., 2017, Spacio-temporal distribution and tourist impact on airborne bacteria in a cave (Škocjan Caves, Slovenia): Diversity, v .9, no. 28, p. 1-14. https://doi.org/10.3390/d9030028.

Nagata, K., Nagata, Y., Sato, T., Fujino, M.A., Nakajima, K., and Tamura, T., 2003, L-Serine, D-and L-proline and alanine as respiratory substrates of Helicobacter pylori: correlation between in vitro and in vivo amino acid levels: Microbiology, v. 149, no. 8, p. 2023-2030. https://doi. org/10.1099/mic.0.26203-0.

Northup, D.E., and Lavoie, K.H., 2001, Geomicrobiology of caves: a review: Geomicrobiology Journal, v. 18, p. 199-222. https://doi. org/10.1080/01490450152467750.

Palmer, A.N., 1991, Origin and morphology of limestone caves: Geological Society of America Bulletin, v. 103, p. 1-21. https://doi.org/10.1130/0016-7606(1991)103<0001:oamolc>2.3.co;2.

Patterson, E.K., Hsiao, S.H., and Keppel, A., 1963, Studies on Dipeptidases and Aminopeptidases I. distinction between leucine aminopeptidase and enzymes that hydrolyze I-leucyl- $\beta$-naphthylamide: Journal of Biological Chemistry, v. 238, no. 11, p. 3611-3620.

Pincus, D.H., 2005, Microbial Identification Using the BioMerieux Vitek® 2 System, in Encyclopedia of Rapid Microbiological Methods, Miller, M.J., ed., Parenteral Drug Association \& Davis Healthcare International Publishing, Moore, OK, 2005; v. II, p. 1-32.

Portillo, M.C., Saiz-Jimenez, C., and Gonzalez, J.M., 2009, Molecular characterization of total and metabolically active bacterial communities of 'white colonization' in the Altamira Cave, Spain: Research in Microbiology, v. 160, p. 41-47. https://doi.org/10.1016/j.resmic.2008.10.002.

Reasoner, D.J., and Geldreich, E.E., 1985, A new medium for the enumeration and subculture of bacteria from potable water: Applied Environmental Microbiology, v. 49, p. 1-7.

Romero, A., 2009, Cave Biology: Life In Darkness, Cambridge University Press, p. 159-181. https://doi.org/10.1017/CBO9780511596841.

Schwartz, T., Hoffmann, S., Obst, U., 2003, Formation of natural biofilms during chlorine dioxide and u.v. disinfection in a public drinking water distribution system: Journal of Applied Microbiology, v. 95, p. 591-601. https://doi:10.1046/j.1365-2672.2003.02019.x.

Shibasaki, T., Mori, H., Chiba, S., and Ozaki, A., 1999, Microbial proline 4-hydroxylase screening and gene cloning: Applied Environmental Microbiology, v. 65, no. 9, p. 4028-4031. https://doi.org/0099-2240/99/\$04.0010.

Shirakawa, M.A., Cincotto, M.A., Atencio, D., Gaylarde, C.C., and John, V.M., 2011, Effect of culture medium on biocalcification by Pseudomonas putida, Lysinibacillus sphaericus and Bacillus subtilis: Brazilian Journal of Microbiology, v. 42, p. 499-507. https://doi.org/10.1590/s151783822011000200014.

Slepecky, R.A., and Hemphill, H.E., 1992, The genus Bacillus-nonmedical: The Prokaryotes, 2nd ed., Springer Verlag, NY; v. III, p 1663. https://doi.org/10.1007/0-387-30744-3_16.

Tisato, N., Torriani, S.F.F., Monteux, S., Sauro, F., De Waele, J., Tavagna, M.L., D’Angeli I.M., Chailloux, D., Renda, M., Eglinton, T.I., and Bontognali, T.R.R., 2015, Microbial mediation of complex subterranean mineral structures: Scientific Reports, v. 5, p. 15525. https://doi. org/10.1038/srep15525.

Tomczyk-Żak, K., and Zielenkiewicz, U., 2015, Microbial diversity in caves: Geomicrobiology Journal, v. 33, p. 20-38. https://doi.org/10.1080/014 90451.2014 .1003341$.

Tomova, I., Lazarkevich, I., Tomova, A., Kambourova, M., and Vasileva-Tonkova, E., 2013, Diversity and biosynthetic potential of culturable aerobic heterotrophic bacteria isolated from Magura Cave, Bulgaria: International Journal of Speleology, v. 42, p. 65-76. https://doi.org/10.5038/1827-806x.42.1.8.

Turkey Cave Database. https://taban.magara.org [accessed: August 15, 2019].

Trevors, J.T., 2011, Viable but non-culturable (VBNC) bacteria: gene expression in planktonic and biofilm cells: Journal of microbiological methods, v. 86, no. 2, p. 266-273. https://doi.org/10.1016/j.mimet.2011.04.018.

Westley, J.W., Anderson, P.J., Close, V.A., Halpern, B., and Lederberg, E.M., 1967, Aminopeptidase profiles of various bacteria: Applied Environmental Microbiology, v.15, no. 4, p. 822-825.

Whitmore, S.E., and Lamont, R.J., 2012, Tyrosine phosphorylation and bacterial virulence: International journal of oral science, v. 4, 1-6. https:// doi/10.1038/ijos.2012.6.

Yılmazusta, N.D., Yakutipekoğlu, H., 2019, An Anthropological Assessment About Burial Practices of Kadıini Cave People (Alanya/Antalya): The Journal of Mediterranean Civilisations Research Institute (MCRI) Cedrus VII, p. 41-58. https://doi.org/10.13113/CEDRUS.201902.

Yücel, S., and Yamaç, M., 2010, Selection of Streptomyces isolates from Turkish karstic caves against antibiotic resistant microorganisms: Pakistan Journal of Pharmacological Science, v. 23, no. 1, p. 1-6.

Zhang, L., Liu, M., Jamil, S., Han, R., Xu, G., and Ni, Y., 2015, PEGylation and pharmacological characterization of a potential anti-tumor drug, an engineered arginine deiminase originated from Pseudomonas plecoglossicida: Cancer Letters, v. 357, p. 346-354. https://doi.org/10.1016/j. canlet.2014.11.042 